\title{
Convection in the western North Atlantic sub- polar gyre: Do small-scale wind events matter?
}

\author{
Robert S. Pickart ${ }^{*}$, Kjetil Våge ${ }^{*}$, G.W.K. Moore ${ }^{\dagger}$, Ian A. Renfrew ${ }^{\ddagger}$, Mads \\ Hvid Ribergaard", Huw C. Davies**
}

\author{
*Woods Hole Oceanographic Institution, Woods Hole, MA 02543, rpickart@whoi.edu \\ ${ }^{\dagger}$ University of Toronto, Toronto, Canada M5S 1A1, gwk.moore@utoronto.ca \\ tUniversity of East Anglia, Norwich, United Kingdom NR4 7TJ, i.renfrew@uea.ac.uk \\ *Danish Meteorological Institute, Copenhagen, Denmark DK-2100, kjetil@whoi.edu, \\ mhri@dmi.dk \\ ${ }^{* *}$ Swiss Federal Institute of Technology, 8092 Zürich, Switzerland, huw.davies@env.ethz.ch
}




\begin{abstract}
This chapter addresses aspects of open-ocean convection in the western North Atlantic, with particular emphasis on the area near southern Greenland and the impact of small-scale atmospheric patterns. Nearly a century ago it was hypothesized that deep convection occurred in the southwest Irminger Sea, and recently convection has been observed in the eastern Labrador Sea. It is argued that the interaction of wintertime low-pressure systems with the high topography of Greenland may lead to the deep mixed-layers in these two areas. Two small-scale atmospheric patterns, forward tip jets and reverse tip jets, result in intense winds on both sides of southern Greenland. The latter pattern is related to the barrier winds along southeast Greenland. In each case the winds blow over areas of closed oceanic circulation where the deep mixing appears to occur. The importance of the forward tip jet in the evolution of the mixed-layer of the southwest Irminger Sea has recently been established, and evidence suggests that during strong winters the overturning can be quite deep. Reverse tip jets may in turn have a similar impact on the eastern Labrador Sea, causing enhanced heat loss and convection. However, to demonstrate this conclusively, further work is necessary to sort out the interaction of the barrier winds and reverse tip jets with the oceanic circulation and pack-ice.
\end{abstract}

\title{
1 Introduction
}

In 1912 the polar explorer and scientist Fridtjof Nansen published an article entitled "Bottom Water and the Cooling of the Ocean", in which he discussed the origin of the deep water in the North Atlantic south of the Greenland-Scotland Ridge (Nansen, 1912). It was known at the time that dense water spills over the ridge system, both through Denmark Strait and between Iceland and the Faroes. Nansen argued, however, that these sources were insufficient to ventilate the vast body of deep water in the North Atlantic basin. He postulated, therefore, that open-ocean convection must be occurring south of the ridge. Furthermore, he suspected that this process was taking place in the Irminger Sea, east of Greenland. He noted that the cyclonic circulation in the Irminger basin (originally documented by Knudsen, 1899) would help keep restratifying waters at the fringes, and 
that the center of the gyre, where the circulation was weak, would be conducive for deep convection.

To test this hypothesis, Nansen organized a research cruise on the Norwegian Gunboat Frithjof in the summer of 1910. His proposed cruise track included a section across the Irminger gyre to the East Greenland shelf near $62^{\circ} \mathrm{N}$. Unfortunately, the Frithjof ran short on coal and never made it to the area. Nansen instead turned to previously collected data from late-winter/early-spring in order to look for evidence of convection. His criterion for overturning was by necessity crude: convection was thought to occur where near-surface properties matched those of the deep water (keep in mind that the measurement uncertainties were quite large in those days). Furthermore, he had very few data to work with, and some of the data were collected outside the immediate area of interest. To his credit Nansen noted this and admitted that his conclusions were tentative. Nonetheless, he stated in the paper that "it is safe to assume that a significant part of the bottom water of the Northern Atlantic Ocean is created in this area." Fig. 1 shows Nansen's schematic circulation of the western North Atlantic, and the region where he believed wintertime convection took place. It is worth noting that the April 1906 data that Nansen used were collected during an extended positive phase of the North Atlantic Oscillation (NAO), which means that the conditions were likely favorable for convective overturning in the western sub-polar gyre (e.g. Dickson et al., 1996). In addition, one of the 1906 stations was located very close to the A1E line of the World Ocean Circulation Experiment (WOCE) within the Irminger gyre. Data from this same area collected in April 1991-during another high-NAO period-were used to argue that deep convection occurs in this vicinity (Pickart et al., 2003a).

Some 21 years after Nansen's article was published, a late-winter cruise to the Irminger Sea was carried out on the German survey vessel Meteor. This was the first wintertime survey of the area, and one of the expressed goals was to evaluate Nansen's ideas regarding convection in the Irminger Sea (Defant, 1936). A follow-on winter cruise was conducted two years later. Based on the vertically uniform distributions of temperature and oxygen from stations occupied during these cruises, to the south and southeast of Cape Farewell (southern tip of Greenland), Wattenberg (1938) concluded that "there can be no doubt that Nansen's opinion voiced in 1912 is accurate." Wüst (1943) later analyzed the density data from the 1933 and 1935 winter cruises and highlighted evidence of overturning to 
$2000 \mathrm{~m}$ due to the near-zero stratification. He noted that this provided "evidence for the correctness of Nansen's hypothesis."

It seems clear then that in the early part of the last century the oceanographic community believed that deep overturning and ventilation occurred southeast of Greenland (additional studies using summertime data supported this notion as well, for instance Baggesgaard-Rasmussen and Jacobsen, 1930; Smith et al., 1937). However, a few years before the German Meteor expeditions to the Irminger Sea, evidence was published that deep convection also occurred in the Labrador Sea (Nielsen, 1928). In fact, Nielsen stated that the Labrador Sea was where "the greater part of the bottom water of the North Atlantic is then evidently formed", which seemed to contradict Nansen's (1912) earlier conclusions. Following Nielsen's (1928) study, the US Coast Guard carried out a series of summertime cruises to the Labrador Sea, from 1928 to 1935. Results from these expeditions were reported by Smith et al. (1937), who were the first to distinguish between intermediate water (which today is known as Labrador Sea Water) and deep and bottom waters. Smith et al. (1937) noted that intermediate water seemed to be formed in the Irminger basin; however, since the German Meteor results were not yet published, Smith et al. (1937) did not comment much further about the situation east of Greenland. They did argue that bottom water was formed via vertical convection only in the Labrador Sea, and their schematic highlighted an isolated area in the central Labrador Sea where this supposedly happened. Since the community was emphasizing bottom water formation at the time, the results of Smith et al. (1937), which were based on extensive profile data, likely had a big impact.

Despite the fact that published papers showed evidence of open-ocean convection on both sides of Greenland, subsequent studies of deep overturning in the western North Atlantic over the following decades were focused primarily on the Labrador Sea (e.g. Lazier, 1973; Worthington, 1976). It is known today that the Labrador basin is indeed the primary source of subpolar mode water in the North Atlantic (e.g. Talley and McCartney, 1982; Rhein et al., 2002). However, it is both interesting and curious that the notion of convection in the Irminger Sea fell completely out of favor. For example, this idea was discounted during planning stages of the North Atlantic WOCE experiment. In recent years, however, the notion has been re-kindled in a series of studies (Pickart et al., 2003a,b; Straneo et al., 2003; Bacon et al., 2003; Falina et al., 2007; Våge et al., 2007). In fact it has been argued that during strong positive phases of the 
NAO, the Irminger Sea may be a significant source of subpolar mode water (Pickart et al., 2003b). If this is the case, then it means that there is a second location, outside of the Labrador Sea, where the atmosphere communicates directly with the deep ocean. This in turn might influence the meridional overturning circulation. It would also require us to revist Labrador Sea Water formation rates and ventilation times, and compel us to interpret both observations and modeling results in a new perspective.

The purpose of this chapter is to summarize the latest thinking about deep convection in the western North Atlantic, emphasizing the region adjacent to southern Greenland studied almost a century ago by Nansen. Much has been published in the intervening years about convection in the western Labrador Sea, including results from the joint Canadian/French field program in the late 1970s (e.g. Clarke and Gascard, 1983) and the recent Labrador Sea Deep Convection Experiment (Lab Sea Group, 1998). These and many other smaller programs have greatly enhanced our understanding of the convective process in the North Atlantic subpolar gyre. However, new revelations about the meteorology around southern Greenland, together with recent oceanographic station data and mooring time series, have called into question the notion of a Labrador Sea-only source of subpolar mode water. The evolution and dynamics of the atmospheric phenomena associated with the high orography of Greenland are different than those for the western Labrador Sea, and the spatial scales are significantly smaller and hence not sufficiently captured in low-resolution meteorological fields. The chapter begins with a brief consideration of convection in the western Labrador Sea. This is followed by a review of the atmospheric patterns associated with southern Greenland, various aspects of which are still emerging. In the remaining part of the chapter we address the ability of the intense winds in this region to force convective overturning in the eastern Labrador Sea and the western Irminger Sea. The ultimate question to be answered is, do these small-scale wind events have a large-scale climatic impact on the ventilation of the North Atlantic?

\section{Convection in the Western Labrador Sea}

Although the occurrence of deep convection in the ocean is fairly easy to discern after the fact, it is a difficult process to observe in real time. This is partly because of the harsh wintertime conditions surrounding this phenomenon (high winds, cold temperatures, rough sea state, and often times ice), and also due to the fact that the lateral scales of the convective plumes 
are very small (Marshall and Schott, 1999). It wasn't until March 1976 that deep convection was directly observed in the Labrador Sea using a shipboard conductivity/temperature/depth (CTD) profiler (Clarke and Gascard, 1983). A typical storm that drives overturning in the western Labrador Sea is shown in Fig. 2. The storms generally follow the North Atlantic storm track past Newfoundland toward Iceland (Hoskins and Hodges, 2002), and the cyclonic circulation draws bitterly cold air off of the Labrador landmass. Total ocean-to-atmosphere heat fluxes from the storms often exceed $500 \mathrm{~W} / \mathrm{m}^{2}$, with the largest fluxes occurring near the marginal ice zone (Renfrew and Moore, 1999; Pagowski and Moore, 2001; Renfrew et al., 2002).

During positive phases of the NAO, the storm track tends to shift to the northeast and the frequency of cyclones increases (Rogers, 1990). While this makes it more conducive for overturning to occur in the western Labrador Sea (Dickson et al., 1996), numerous other factors come into play. These include: (1) advection of freshwater from the Arctic, for instance the great salinity anomaly (Dickson et al., 1988) that shut down convection in the early 1970s (Talley and McCartney, 1982), as well as other smaller events in the 1990s (Belkin et al., 1998); (2) interannually varying input of warm and salty subtropical water (Curry et al., 1998); and (3) the "memory" of the system (e.g. Straneo and Pickart, 2001). Since it takes roughly 5-6 years for all of the Labrador Sea Water to be flushed from the basin after formation (Yashayaev, 2007), this means that repeated winters of deep convection will prime the system for continued overturning even if a subsequent winter is not very cold or windy. This was the case for the winter of 1996-7 which produced deep convection with only moderate atmospheric forcing over much of the season (Pickart et al., 2002).

Although the region of strong heat flux from storms such as that in Fig. 2 is fairly broad, convection does not readily occur over the entire Labrador basin. This is partly due to the circulation of the sea. As explained in Marshall and Schott (1999), one of the factors, in addition to the atmospheric forcing, that promotes convection is the presence of cyclonic circulation. This both weakens the upper-layer stratification due to the doming of the isopycnals, and traps the water thereby allowing numerous storms to influence the same water parcels. The circulation of the western subpolar gyre consists of a strong boundary current over the continental slope, and a series of closed cyclonic recirculations adjacent to this (Lavender et al., 2000; Fig. 3). It has been argued that these recirculations are driven by the enhanced wintertime windstress curl to the east of Greenland 
(see below), governed by the dynamics of topographic beta plumes (Spall and Pickart, 2003). As seen in Fig. 3, it is clear that the deepest mixedlayers in the Labrador Sea occur within the recirculations. This notion is supported as well by the observations of Clarke and Gascard (1983), Pickart et al. (2002), and Lavender et al. (2002).

A second factor controlling the spatial extent of convection in the Labrador Sea is the eddy field. It is now known that the eastern boundary of the sea, near $61-62^{\circ} \mathrm{N}$, is a source of eddy formation, apparently due to both barotropic and baroclinic instability of the boundary current (Eden and Böning, 2002; Katsman et al, 2004; Bracco and Pedlosky, 2003). One of the main factors is the local variation in topographic slope, which is conducive for instability (Wolfe and Cenedese, 2006). The anti-cyclones formed from this region are long-lived and generally translate to the southwest (Prater, 2002; Lilly et al., 2003). These features contain warm and salty boundary current water in their cores (hence the name Irminger Rings, Lilly et al., 2003), and they are an effective means of transporting buoyant water into the interior. This is believed to play an important role in the restratification after convection (Katsman et al., 2004), and also seems to influence the location where the deepest convection occurs in the basin. Note in Fig. 2 that the heat loss due to the storms is strong in the northern Labrador Sea, within one of the regions of cyclonic circulation (Fig. 3). This implies that deep convection should occur there, but observations show that the spreading of buoyant water from the boundary by the Irminger rings inhibits deep overturning (Pickart et al., 2002). This is consistent with the distribution of surface eddy speed (Fig. 3) which shows that the northeast part of the basin is strongly influenced by the eddies. The low occurrence of deep mixed-layers in this region (Fig. 3) implies that the eddy field helps to confine the deepest overturning to the western part of the basin.

The newly convected Labrador Sea Water leaves the basin by one of three general pathways (Talley and McCartney, 1982). The first pathway is in the Deep Western Boundary Current, which is an effective means of transporting the water to the subtropics (e.g. Molinari et al, 1998; Pickart et al., 1997). The second pathway is with the North Atlantic Current, which advects the water to the eastern Atlantic (e.g. Read and Gould, 1992). The third pathway is into the Irminger basin. It is this pathway that lies at the heart of the issue of whether or not Labrador Sea Water is formed entirely within the Labrador basin. Based on hydrographic data and models, it has recently been established that the travel time for Labrador Sea Water to reach the Irminger Sea via this pathway is approximately two 
years (Pickart et al., 2003a; Yashayaev et al., 2007; Falina et al., 2007; Kvalberg et al., 2007a). This raises the possibility that past observations of relatively newly convected Labrador Sea Water in the Irminger basin might have been incorrectly interpreted as local formation south and east of Greenland. Judging by the station map of Defant (1936), it is possible that some of the data from the 1935 Meteor cruise that validated Nansen's hypothesis were in fact taken within this pathway from the Labrador Sea. However, this is unlikely the case for all of the stations. Furthermore, based on recently collected hydrography, the distribution of Labrador Sea Water within the Irminger basin is inconsistent with a Labrador Sea-only source.

Sy et al. (1997) argued that, in the mid-1990s, Labrador Sea Water took only 6 months to reach the Irminger basin, which is inconsistent with the above estimates and the model results. Furthermore, using early springtime measurements, Pickart et al. (2003a) showed that if this pathway were the sole means by which Labrador Sea Water entered the Irminger basin, then the advective time scale would at times have to be less than three months. This is clearly unrealistic, especially since the observations of Pickart et al. (2003a) were taken inside the Irminger gyre. Advectivediffusive models (Straneo et al., 2003; Kvalberg et al., 2007) show that it takes on the order of three years for Labrador Sea Water to penetrate the gyre from the outside. Additionally, observations collected during the most recent positive phase of the NAO during the early 1990s show two separate extrema of weak mid-depth stratification: one in the western Labrador Sea, and one in the southwest Irminger Sea (Fig. 4). It is impossible to reproduce such a lateral tracer pattern from a single source of convection in the Labrador Sea (Straneo et al., 2003), and the double-source of Labrador Sea Water considered by Kvalberg et al. (2007) fits the observations better. Next, we discuss new insights regarding the atmospheric patterns associated with the high orography of Greenland-patterns that are conducive for convective overturning in the vicinity of Cape Farewell.

\section{Wintertime atmospheric circulation near southern Greenland}

The high topography of Greenland ( $>3000 \mathrm{~m}$ ) plays a critical role in the atmospheric patterns affecting the western North Atlantic Ocean. In a broad-scale sense the orography of Greenland influences the Icelandic low (e.g., Kristjansson and McInnes, 1999; Petersen et al., 2004) and the associated North Atlantic Oscillation, which in turn impacts the state of the 
subpolar gyre and its interannual variability (e.g., Dickson et al., 1996; Häkkinen and Rhines, 2004). On smaller scales, the topography of Greenland exerts an enormous influence on local weather systems and on the passage of individual storms (e.g., Cappelen et al, 2001; Doyle and Shapiro, 1999). Recent advances from improved atmospheric mesoscale models (e.g., MM5, HIRLAM) and high-resolution observations (QuikSCAT) have offered new glimpses into the structure and dynamics of these features. In wintertime, several distinct atmospheric patterns dominate, each of them associated with strong low level winds $(>20 \mathrm{~m} / \mathrm{s})$ over different parts of the western Irminger Sea and eastern Labrador Sea. Here we limit the discussion of these patterns to the region near Cape Farewell. One should keep in mind that the length scales of the features in question (often as small as tens of kilometers) make them difficult to detect in the relatively low-resolution global meteorological analyses (e.g. from NCEP or ECMWF). At the same time, proper representation of these features and the associated air-sea heat transfer can be important for short- and medium-term weather prediction. Sensitivity analyses often indicate that the specification of the initial conditions in this region can exert a significant impact on the subsequent forecast.

\subsection{Forward Greenland tip jet}

The North Atlantic storm track generally steers low pressure systems northeastward past Newfoundland towards the southern Labrador Sea, and into the vicinity of Greenland and Iceland (Hoskins and Hodges, 2002). Most of the storms pass east of Greenland into the Irminger Sea (Serreze et al., 1997), although sometimes they enter the Labrador Sea (Vagge et al, 2007). Occasionally a storm splits due to the presence of Greenland, and the secondary low enters the Labrador Sea (Petersen et al., 2003). Along the storm track, intense cyclogenesis occurs in the region between Newfoundland and Greenland (Serreze et al., 1997; Tsukernik et al., 2007). There is, however, a second region of storm enhancement in the southern Irminger Sea, which is largely fueled by the strong surface gradient between the cold waters of the east Greenland shelf (and sometimes ice) and the warmer interior waters of the Irminger basin (Tsukernik et al., 2007). While the large-scale circulation associated with these intense cyclones is strong, the magnitude of the winds around southern Greenland is often significantly greater than would be expected from the storms alone. This is because of interaction of the cyclones with the high orography of Greenland. 
In the vicinity of Cape Farewell, the wintertime winds tend to be bimodal-either predominantly westerly or northeasterly. This is seen in the long-term weather station data from Prins Christian Sund (Fig. 5). While there may be fjord effects associated with this record, it is consistent with the shorter-term QuikSCAT wind measurements from this area collected since 1999 (Moore and Renfrew, 2005). The first of these modes is associated with a phenomenon known as the forward Greenland tip jet, a name given by Doyle and Shapiro (1999) who were the first to study this phenomenon (although weather forecasters have known about this condition for decades, L. Rasmussen pers. comm., 2002). A forward tip jet is an intense, episodic westerly wind that often develops when the center of a low pressure system passes to the northeast of Cape Farewell (Fig. 6a). Based on nearly 40 years of Prins Christian Sund weather station, the average duration of a tip jet event is three days, and, climatologically, they occur every 10 days during the months of December through March (Pickart et al., 2003b). However, the QuikSCAT data suggest that they occur even more frequently (because their path sometimes misses the weather station), while the strongest winds generally persist for less than 24 hours (Våge et al, 2007). The number of tip jets in a given winter varies interannually and is significantly correlated with the NAO index. More events tend to occur during a higher NAO winter (Pickart et al., 2003b), and the latitude of the center of action of the NAO also impacts their frequency (Bakalian et al., 2007).

What specific factors cause the tip jets to develop? There are two contributing circumstances. Doyle and Shapiro (1999) argue that the westerly winds intensify via acceleration during orographic descent from the Greenland plateau, due to the air parcels conserving Bernoulli function. Doyle and Shapiro (1999), Petersen et al.(2004) and Moore and Renfrew (2005) also discuss a second mechanism of acceleration associated with flow splitting or flow distortion. This occurs as the air parcels intercept the topographic barrier of Greenland and are forced around and/or over it, depending on the atmospheric stability and barrier dimensions (i.e. the Froude number). Neither Doyle and Shapiro (1999) nor Moore and Renfrew (2005) were able to sort out the precise relationship between, or relative contributions of, these two mechanisms.

In an effort to shed light on this, Våge and Davies (2007) studied tip jet events using the ERA-40 reanalysis data set. Using an empirical orthogonal function approach, more than 500 events were identified over the time period 1957-2002. The 3-D trajectory model Lagranto (Wernli and 
Davies, 1997) was applied to a subset of these events to compute backward air parcel trajectories terminating in the southern Irminger Sea. Nearly 3000 back-trajectories were considered, emanating from approximately 100 tip jet events. The results demonstrate that the vast majority of the air parcels curve around the southern tip of Greenland and accelerate (Fig. $7 \mathrm{a})$. There is, however, some vertical descent involved, associated with the edge of the Greenland landmass (Fig. 7b). This suggests that both flow splitting and orographic descent play a role in the development of the tip jet, but that most air parcels remain over the ocean. Fig. 7a shows that maximum tip jet velocities exceeding $20 \mathrm{~m} / \mathrm{s}$ occur east of Cape Farewell. It should be noted, however, that the wind speeds from ERA-40 are significantly less than those observed concurrently from QuikSCAT (Våge and Davies 2007), and individual tip jet events can be as strong as $50 \mathrm{~m} / \mathrm{s}$ (Fig. 6a).

\subsection{Reverse Greenland tip jet}

The second dominant wintertime air pattern near Cape Farewell is an intermittent northeasterly wind known as a reverse tip jet (Fig. 6b), a name given by Moore (2003) and Moore and Renfrew (2005) who studied this phenomenon using QuikSCAT data. These events are also associated with the passage of cyclones, although the storm centers are located south of Greenland (Fig. 6b), in contrast to the forward tip jet case where the storms are located northeast of Cape Farewell. As mentioned above, the occurrence of strong northeasterly winds in this region has long been established, and is related to the barrier winds along the southeast coast of Greenland (Cappelen et al., 2001). Essentially, the cyclonic winds associated with the storm impinge upon the topographic barrier of Greenland, which causes a damming of the cold air and the establishment of a crossshelf pressure gradient. This leads to strong northeasterly winds that accelerate further near the tip of Greenland where the barrier disappears. As explained in Moore and Renfrew (2005), the increase in wind speed is related to the anticyclonic curvature of the trajectories in the absence of the barrier, consistent with an inertial force balance in this region. Wind speeds immediately south and west of Cape Farewell can be very strong during these events (Fig. 6b). While less is known about the climatology of the reverse tip jets-for instance their frequency, typical duration, and relationship to the NAO - both the meteorological station measurements near Cape Farewell (Fig. 5) and the QuikSCAT satellite data (Moore and Renfrew, 2005) indicate that they are a common wintertime phenomenon. 
The kinematics, dynamics and air-sea fluxes associated with tip jets, reverse tip jets and barrier winds around southern Greenland are the subject of considerable interest at the moment. An international aircraft-based field program took place during February-March 2007 called the Greenland Flow Distortion experiment, with one aim being to collect the first comprehensive in situ observations of such features. The experiment obtained an array of observations via dropsondes at high- and low-levels (down to 100 feet) of a reverse tip jet event, several barrier flow events, and also a lee cyclogenesis event that took place just east of Cape Farewell. It is too early to highlight any significant results, but a preliminary look at the observations reveals, for example, reverse tip jet core wind speeds near $50 \mathrm{~m} / \mathrm{s}$ and significant off-ice barrier flow heat fluxes.

\section{Impact of small-scale wind patterns on oceanic convection}

There is increasing evidence that the small-scale atmospheric flow patterns described above have a significant impact on the western North Atlantic subpolar gyre-both in terms of convective overturning and in regards to certain aspects of the circulation. Since more research has been done on the consequences of the forward tip jet, we discuss this first.

\subsection{Convection in the western Irminger Sea}

Two aspects of the forward Greenland tip jet are of particular importance to the ocean. The first is the meridional length scale of the jet, and in particular the sharp gradient in wind speed to the north of the jet axis. Often times the wind decreases significantly over a very short distance. For example, in Fig. 6a, to east of Cape Farewell, the westerly wind speed diminishes to the north by $15 \mathrm{~m} / \mathrm{s}$ in just $50 \mathrm{~km}$. Such sharp gradients result in very large synoptic values of cyclonic windstress curl, nearly three orders of magnitude larger than the broad-scale curl of the North Atlantic (Pickart et al., 2003b). Fig. 8 shows the composite wind stress curl from 7 years of QuikSCAT data, where the year has been divided into winter (Nov-Apr) and summer (May-Oct). The frequent storms in winter result in a band of strong cyclonic curl along southeast Greenland (Fig. 8a), due largely to the barrier winds. The strongest positive curl occurs east of Cape Farewell and is clearly the result of the forward tip jet (as is the enhanced negative curl 
west of Cape Farewell). Note that this curl signature largely vanishes during the summer (Fig. 8b). The forward tip jet is thus a major contributor to the enhanced seasonal cyclonic curl pattern near southern Greenland

This vorticity distribution in turn has a significant impact on the circulation of the subpolar gyre. According to the numerical model study of Spall and Pickart (2003), the enhanced positive curl drives the cyclonic recirculation in the western Irminger and Labrador Seas (Fig. 3). Even though the wind forcing is seasonal, a steady circulation develops because of the slow baroclinic wave response at this latitude (wave speeds roughly $1 \mathrm{~cm} / \mathrm{s}$ ), together with the effect of the bottom topography which causes the deep circulation to dampen the seasonal response. The bottom topography also helps to form the multiple areas of closed streamlines along the lower continental slope (Kvalberg and Haine, 2007). Pickart et al. (2003b) showed that frequent tip jets alone (i.e. without any barrier winds) can drive the Irminger gyre. Hence, the tip jet is largely responsible for the trapping of water near the region of southern Greenland, as well as for the doming of the isopycnals in this area. Both of these factors help facilitate deep convection (Marshall and Schott, 1999).

The second crucial aspect of forward tip jets is the large heat flux that results from the cold air being advected over the warm ocean. This was recognized by Doyle and Shapiro (1999), and subsequently studied by Pickart et al. (2003b), Centurioni and Gould (2004), and Våge et al. (2007). Using a numerical model forced by a sequence of tip jets associated with a strong winter, Pickart et al. (2003b) showed that deep convection can occur in the southwest Irminger Sea. The area of overturning in the model corresponded with the observed extremum in mid-depth potential vorticity to the east of Cape Farewell (Fig. 9). This provided compelling evidence that the Labrador Sea is not the sole source of the subpolar mode water of the western North Atlantic, and solved the puzzle regarding the unrealistically fast travel times into the Irminger Sea deduced from measurements during the 1990's high phase of the NAO. However, the model configuration as well as the forcing used by Pickart et al. (2003b) were idealized, and direct wintertime measurements of deep convection in the Irminger Sea are still lacking today.

Unfortunately, during the period of active mode water formation in the early 1990s there were no wintertime cruises to the Irminger Sea. Furthermore, the PALACE/ARGO profiling float programs (e.g. Lavender et al., 2000, 2002; Centurioni and Gould, 2004) had not yet begun. It wasn't until 1997 onward that the floats were able to measure the seasonal devel- 
opment of the mixed-layer in the western subpolar gyre, but by this time the winters had become more moderate and convection had diminished considerably in the Labrador Sea (Lazier et al., 2002). Nonetheless, the float data were used by Bacon et al. (2003) and Centurioni and Gould (2004) to demonstrate that overturning to depths of 400-700 m did occur during this period in the western Irminger Sea. Centurioni and Gould (2004) also used several 1-D mixed-layer models, forced by an idealized representation of the forward tip jet, to show that tip jets were likely responsible for the observed convection.

In an effort to elucidate the role of the Greenland tip jet on convection in the Irminger Sea, a subsurface mooring was deployed east of Cape Farewell in August 2001, in the region of the low potential vorticity (see Fig. 4). The mooring contained a McLane CTD profiler with an acoustic current meter, and was programmed to return two vertical traces per day between $55 \mathrm{~m}$ and $1800 \mathrm{~m}$. Unfortunately the profiler failed the first year, but did successfully profile through the winter during the next two deployments (2002-03 and 2003-04). Since these winters were characterized by a low value of the NAO index, it was not expected that deep convection would occur at the site. Nonetheless, using the CTD data together with a variety of atmospheric data sets, Våge et al. (2007) demonstrated that the Greenland tip jet plays a dominant role in the wintertime deepening of the mixed-layer in the western Irminger Sea.

As mentioned above, the small meridional scale of the tip jet (order $100 \mathrm{~km}$ or less) makes it difficult to resolve in the global meteorological fields. As such, Våge et al (2007) constructed an improved heat flux time series at the mooring site using bulk formulae together with various surface data. For winds the QuikSCAT data were used, for sea surface temperature the (extrapolated) mooring time series was used, for air temperature the weather station data from Cape Farewell were used, and for relative humidity the NCEP data were used. The latter two time series were adjusted for the mooring site using meteorological buoy data collected at the site during the fall of 2004 (see Vagge, 2006). The resulting total heat flux, averaged over the winter of 2002-03, was more than $30 \%$ larger than that from NCEP alone. The biggest discrepancy occurred during the tip jet events. For the 12 robust events between December and April, the average heat flux from NCEP was $267 \mathrm{~W} / \mathrm{m}^{2}$, compared to a value of $413 \mathrm{~W} / \mathrm{m}^{2}$ from the improved estimate-an increase of $55 \%$.

Not surprisingly, this extra heat flux has a significant impact on the evolution of the mixed-layer. To demonstrate this Våge et al. (2007) ran 
the Price et al. (1986) 1-D mixed-layer model on a CTD profile from November 2002, forced with both the NCEP heat flux timeseries and the improved heat flux product. As seen in Fig. 10, the mixed-layer depth predicted from NCEP alone (red curve) is too shallow compared to the observations from the mooring, whereas the depth from the improved heat flux timeseries (blue curve) does a much better job tracking the envelope of deepest observed mixed-layer depth (black curve). (The high frequency signal in the observations is likely due to the effects of lateral advection, which is not captured by the 1-D model.) To quantify the effect of the intermittent wind events, a third model run was performed in which the tip jets were removed from the improved heat flux timeseries (green curve in Fig. 10). It is clear that the heat loss due to the succession of tip jet events over the course of the winter had a sizable impact on the final depth of convection.

One of the remaining questions is, can the forward tip jet cause deep convection during high NAO winters? It will be impossible to address this with observations until the return of cold and stormy winters to the western North Atlantic. However, Våge et al. (2007) have shown that the answer is likely yes. During the early 1990s there were on average more robust tip jet events per winter and overall stormier conditions (Pickart et al., 2003b), plus the water column in the Irminger Sea was better preconditioned for overturning. Våge et al. (2007) initialized the mixed-layer model with a CTD profile from fall 1994, and forced the model with a similarly computed improved heat flux timeseries for the winter of 1994-95. The predicted final depth of convection for this calculation was nearly $1800 \mathrm{~m}$ (Fig. 11), consistent with hydrographic data collected in this region the following summer (Pickart et al., 2003a). This is roughly $1000 \mathrm{~m}$ deeper than predicted using NCEP alone, and, as was true for the winter of 200203 , the presence of the tip jets had a significant impact.

\subsection{Convection in the eastern Labrador Sea}

One of the interesting results from Lavender et al.'s (2002) study was the occurrence of relatively deep convection in the eastern Labrador Sea (east of $50^{\circ} \mathrm{W}$, see Fig. 3). While the observations are few (the NAO index was low during the time period of their measurements), the deep mixed-layers occurred within the recirculation gyre to the southwest of Cape Farewell. This sub-basin scale gyre seems to be a robust feature of the Labrador Sea circulation, since it was also measured by surface drifters in the area (Ja- 
kobsen et al., 2003). Does the reverse tip jet play a role in the convection here? As discussed by Moore and Renfrew (2005), reverse tip jets are intimately tied to the barrier winds along the southeast Greenland coast. The winds tend to veer toward the Labrador Sea after the barrier ends, bringing the air carried by the jet directly over the region of closed oceanic circulation (Fig. 12). If the air is cold and dry enough, this would result in enhanced heat loss within the gyre, satisfying the set of conditions for convection: trapped water, domed isopycnals, and strong ocean-toatmosphere heat loss.

While the reverse tip jet is a dominant feature in the wintertime wind climatology of the region (Moore and Renfrew, 2005), there has been no in-depth study yet carried out of the characteristics and impact of the individual events. Hence, unlike the case of the forward tip jet, no quantitative conclusions can be drawn regarding the ability of the reverse tip jets to force convection. However, circumstantial evidence suggests that, during high NAO winters, this may be the case. During winter, pack-ice forms along the East Greenland shelf all the way to Cape Farewell, and, in strong winters, the ice cover can extend the full width of the shelf. As an example consider Fig. 13, which shows the ice concentration in mid-March 2007. At this time a band of $70-90 \%$ concentration extended to the tip of Greenland. Hence, during any reverse tip jet events, the barrier winds would flow along the ice before veering into the eastern Labrador Sea (compare Figs. 12 and 13). The strongest heat loss would thus occur beyond the ice edge, directly over the closed gyre. This is akin to the western Labrador Sea where the strongest heat loss is immediately east of the ice edge (Fig. 2).

This scenario of course needs verification, and there are other factors that require consideration. For example, the southeast Greenland shelf is a dynamic area with strong surface currents (e.g. Bacon et al., 2002; Sutherland and Pickart, 2007). The pack-ice can vary synoptically depending on these currents as well as on the local wind field (K. Hansen, pers. comm., 2006), and it is not obvious how important such variability is over an entire winter. Another factor is the upstream history of the air parcels that form the barrier winds, and whether or not the air emanating from the tip of Greenland is indeed cold and dry enough to cause significant heat loss. A third factor to consider is the impact of the westerly winds that blow over the sea during typical Labrador Sea storms. In the example of Fig. 2 the heat loss in the eastern part of the basin is moderate, but one could envision stronger storms with enhanced heat flux in the vicinity of Cape Farewell. Hence, the relative roles of the reverse tip jets, the ice field, and 
the general storminess of the Labrador Sea in driving convection in the eastern part of the basin remains to be determined. It is worth noting that convection here might also help precondition the water that makes it to the western side of the basin later in the winter via the boundary current.

\section{Conclusions}

It has been shown in this chapter that measurements taken nearly a century ago near Cape Farewell, which hinted of deep convection, may in fact have revealed the ocean's response to small-scale wind patterns caused by the high topography of Greenland. Recent satellite-based observations from QuikSCAT, high-resolution aircraft measurements, and mesoscale atmospheric models have begun to shed light on the complex nature of the atmospheric circulation near the tip of Greenland. Both forward tip jets and reverse tip jets are associated with intense winds that geographically correspond to regions of deep oceanic mixed-layers. The impact of the forward tip jets on the southwest Irminger Sea is more established at this point, including the importance of the strong cyclonic windstress curl and enhanced heat flux. While the reverse tip jets are an obvious candidate for the observed deep mixing in the eastern Labrador Sea, the heat flux resulting from these events still needs to be quantified.

Further research on a variety of fronts is necessary to establish more concretely the connection between these atmospheric phenomena and the ocean circulation and convection. For example, the dynamics of the air patterns-particularly the impact of the orography of Greenland-needs to be elucidated to understand why these patterns arise in the first place. The role of the large-scale storm climate in dictating their frequency and strength needs to be better established. The ability of the air patterns to drive the ocean, both through windstress curl input and buoyancy forcing, requires more detailed consideration. This is especially true for the reverse tip jets, including the role of the pack-ice. Finally, concurrent observations of the atmosphere and ocean, especially during robust winters, are crucial if we are to understand better how such small-scale atmospheric patterns impact the ocean on climatically relevant time and space scales.

\section{Acknowledgments}

The authors acknowledge the following funding agencies for this work. National Science Foundation grant OCE-0450658 (RP and KV); Canadian Foundation for Climate and Atmospheric Sciences (GWKM); Nordic Council of Ministers-West-Nordic Ocean Climate (MHR). 


\section{References}

Bacon S et al. (2002) A freshwater jet on the east Greenland shelf. Journal of Geophysical Research 107:10.1029/2001JC000935

Bacon S et al. (2003) Open-ocean convection in the Irminger Sea. Geophysical Research Letters 30:doi:10.1029/2002GL016271

Baggesgaard-Rasmussen, Jacobsen JP (1930) Contribution to the hydrography of the waters round Greenland in the year 1925. Medd. fra Kommissionen for Havundersogelser, Serie I, Hydrografi, Bd I, 2:10, pp 24

Bakalian F et al. (2007) Influence of the Icelandic Low latitude on the frequency of Greenland tip jet events: Implications for Irminger Sea convection. Journal of Geophysical Research 112:C04020:doi:10.1029/2006JC003807

Belkin IM et al. (1998) "Great Salinity Anomalies" in the North Atlantic. Progress in Oceanography $41: 1-68$

Bracco A, Pedlosky J (2003) Vortex generation by topography in locally unstable baroclinic flows. Journal of Physical Oceanography 33:207-219.

Bracco A. et al. (2007) Eddy formation near the west coast of Greenland. Journal of Physical Oceanography submitted

Cappelen J et al. (2001) The observed climate of Greenland, 1958-99, with climatological standard normals, 1961-90. Technical Report 00-18, Danish Meteorological Institute, Copenhagen, Denmark

Centurioni LR, Gould WJ (2004) Winter conditions in the Irminger Sea observed with profiling floats. Journal of Marine Research 62:313-336

Clarke RA, Gascard JC (1983) The formation of Labrador Sea water. Part I: Large-scale processes. Journal of Physical Oceanography 33:1764-1778

Curry RG et al. (1998) Oceanic transport of subpolar climate signals to mid-depth subtropical waters. Nature 391:575-577

Defant A (1936) Bericht uber die ozeanographischen Untersuchungen des Vermessungsschiffes "Meteor" in der Danemarkstrasse und in der Imingersee. Preuss. Akad.d. Wiss., Sitz., Phys.Math. Klasse XIX:232-242

Dickson RR et al. (1988) The "Great Salinity Anomaly" in the Northern North Atlantic 1968-1982. Progress in Oceanography 20:103-151

Dickson RR et al. (1996) Long-term coordinated changes in the convective activity of the North Atlantic. Progress in Oceanography 38:241-295

Doyle JD, Shapiro MA (1999) Flow response to large-scale topography: The Greenland tip jet. Tellus 51MA:728-748 
Eden C and Böning C (2002) Sources of eddy kinetic energy in the Labrador Sea. Journal of Physical Oceanography 32:3346-3363

Falina A et al. (2007) Variability and renewal of Labrador Sea Water in the Irminger Basin in 1991-2004. Journal of Geophysical Research 112:C01006, doi:10.1029/2005JC003348

Hakkinen S, Rhines PB (2004) Decline of the subpolar North Atlantic circulation during the 1990s. Science 304:555-559

Hoskins B, Hodges K (2002) New perspectives on the northern hemisphere winter storm tracks. Journal of the Atmospheric Sciences 59:1041-1061

Jakobsen PK et al. (2003) Near-surface circulation in the northern North Atlantic as inferred from Lagrangian drifters: Variability from the mesoscale of interannual. Journal of Geophysical Research 108:doi:10.1029/2002JC001554

Katsman CA et al. (2004) Boundary current eddies and their role in the restratification of the Labrador Sea Journal of Physical Oceanography 34:967-1983

Kvaleberg E et al. (2007a) Spreading of CFC-11 in the subpolar North Atlantic Ocean. Journal of Geophysical Research submitted

Knudsen M (1899) Hydrography. Danish Ingolf Expedition. Bd. I, No. 2. Kopenhagen

Kristjansson JE, McInnes H (1999) The impact of Greenland on cyclone evolution in the North Atlantic. W J R Meteorological Society 125:2819-2834

Labsea Group (1998) The Labrador Sea deep convection experiment. Bulletin of the American Meteorological Society 79:2033-2058

Lavender KL et al. (2000) Mid-depth recirculation observed in the interior Labrador and Irminger Seas by direct velocity measurements. Nature 407:66-69

Lavender KL et al. (2002) Observations of open-ocean deep convection in the Labrador Sea from subsurface floats. Journal of Physical Oceanography 32:511-526

Lazier JRN (1973) The renewal of Labrador Sea water. Deep-Sea Research 20:341-353

Lazier JRN et al. (2002) Convection and restratification in the Labrador Sea, 1990-2000. Deep Sea Research 49:1819-1835

Lilly JM et al. (2003) Observations of the Labrador Sea eddy field. Progress in Oceanography 59:75-176

Marshall J, Schott F (1999) Open-ocean convection: observations, theory, and models. Reviews of Geophysics 37:1-64

Molinari RL et al. (1998) The arrival of recently formed Labrador Sea Water in the deep western boundary current at 26.5N. Geophysical Research Letters 25:2249-2252

Moore GWK (2003) Gale force winds over the Irminger Sea to the east of Cape Farewell Greenland. Geophysical Research Letters 30:184-187 
Moore GWK, Renfrew IA (2005) Tip jets and barrier winds: A QuickSCAT climatology of high wind speed events around Greenland. Journal of Climate 18:3713-3725

Nansen F (1912) Das bodenwasser und die abkuhlung des meeres. Internationale Revue der gesamten Hydrobiologie und Hydrographie Band V, Nr. 1:1-42

Nielsen J (1928) The waters around Greenland. In: Greenland. The discovery of Greenland, exploration, and the nature of the country. I:185-230

Pagowski M, Moore GWK (2001) A numerical study of an extreme cold-air outbreak over the Labrador Sea: Sea-ice air-sea interaction and the development of polar lows. Monthly Weather Review 129:47-72

Petersen GN et al. (2003) Flow in the lee of idealized mountains and Greenland. Journal of the Atmospheric Sciences 60:2183-2195

Petersen GN et al. (2004) Numerical simulations of Greenland's impact on the northern hemisphere winter circulation. Tellus 56A:102-111

Pickart RS et al. (1997) Mid-depth ventilation in the western boundary current system of the sub-polar gyre. Deep-Sea Research I 44:1025-1054

Pickart RS et al. (2002) Hydrography of the Labrador Sea during active convection. Journal of Physical Oceanography 32:428-457

Pickart RS et al. (2003a) Is Labrador Sea Water formed in the Irminger Basin? Deep-Sea Research I 50:23-52

Pickart RS et al. (2003b) Deep convection in the Irminger Sea forced by the Greenland tip jet. Nature 424:152-156

Prater MD (2002) Eddies in the Labrador Sea as observed by profiling RAFOS floats and remote sensing. Journal of Physical Oceanography 32:411-427

Price J et al. (1986) Diurnal cycling: Observations and models of the upper ocean response to diurnal heating, cooling, and wind mixing. Journal of Geophysical Research 91:8411-8427

Read J F, Gould WJ (1992) Cooling and freshening of the sub-polar North Atlantic ocean since the 1960's. Nature 360:55-57

Renfrew IA, and Moore GWK (1999) An extreme cold-air outbreak over the Labrador Sea: roll vortices and air-sea interaction. Monthly Weather Review 127:2379-2394

Renfrew IA et al. (2002) A comparison of surface-layer heat flux and surface momentum flux observations over the Labrador Sea with ECMWF analyses and NCEP reanalyses. Journal of Physical Oceanography 32:383-400

Rhein M et al. (2002) Labrador Sea water: pathways, CFC-inventory, and formation rates. Journal of Physical Oceanography 32:648-665

Rogers JC (1990) Patterns of low-frequency monthly sea level pressure variability (1899-1986) and associated wave cyclone frequencies. Journal of Climate 3:1364-1379 
Serreze MC et al. (1997) Icelandic low cyclone activity: climatological features, linkages with the NAO, and relationships with recent changes in the northern hemisphere circulation. Journal of Climate 10:453-464

Smith EH et al. (1937) The Marion and General Greene expeditions to Davis Strait and Labrador Sea. Scientific results, Part 2, physical oceanography. Bulletin US Coast Guard 19:1-259

Spall MA, Pickart RS (2003) Wind-driven recirculations and exchange in the Labrador and Irminger Seas. Journal of Physical Oceanography 33:1829-1845

Straneo F, R.S. Pickart RS (2001) Interannual variability in Labrador Sea Water formation and export: How does it correlate to the atmospheric forcing? U.S. CLIVAR Meeting, June 2001, extended abstract volume

Straneo F et al. (2003) Spreading of Labrador Sea water: An advective-diffusive study based on Lagrangian data. Deep-Sea Research I 50:701-719

Sutherland DA, Pickart RS (2007) The East Greenland coastal current: Structure, variability, and forcing. Progress in Oceanography submitted

Sy A et al. (1997) Surprisingly rapid spreading of newly formed intermediate waters across the North Atlantic Ocean. Nature 386:675-679

Talley LD, McCartney MS (1982) Distribution and circulation of Labrador Sea Water. Journal of Physical Oceanography 12:1189-1205

Tsukernik M et al. (2007) Characteristics of winter cyclone activity in the northern North Atlantic: Insights from observations and regional modeling. Journal of Geophysical Research in press

Våge K (2006) Winter mixed-layer development in the central Irminger Sea: The effect of strong, intermittent wind events. Master's Thesis, Massachusetts Institute of Technology and Woods Hole Oceanographic Institution Joint Program in Oceanography and Oceanographic Engineering, Woods Hole Oceanographic Institution, pp 79

Våge K et al. (2007) Winter mixed-layer development in the central Irminger Sea: The effect of strong, intermittent wind events. Journal of Physical Oceanography submitted

Våge K, Davies HC (2007) The Greenland tip jet from the ERA-40 reanalysis. Manuscript in preparation

Wattenberg H (1938) Die Verteilung des sauerstoffs im Atlantishcen Ozean. Verlag Von Walter de Gruyter \& Co., Berlin, pp 132

Wolfe CL, Cenedese C (2006) Laboratory experiments on eddy generation by a buoyant coastal current flowing over variable topography. Journal of Physical Oceanography 36:395-411

Worthington LV (1976) On the North Atlantic circulation. The Johns Hopkins Oceanographic Studies, 6, pp 110

Wüst G (1943) Der subarktische bodenstrom in der westatlantischen mulde. Annanlen der Hydrographie und Maritimen Meteorologie Heft IV/VI:249-256 
Yashayaev I et al. (2007) Spreading of the Labrador Sea Water to the Irminger and Iceland basins. Geophysical Research Letters 34:L10602, doi:10.1029/2006GL028999

Yashayaev I (2007) Hydrographic changes in the Labrador Sea, 1960-2005. Progress in Oceanography in press 
Fig 1. Nansen's (1912) schematic of the circulation and region of deep convection (his figure 8 ). The area of overturning is delimited by the dotted line, most of which was thought to occur adjacent to southeast Greenland within the recirculating gyre of the Irminger Sea.

Fig 2. Typical Labrador Sea winter storm (16 Feb 1997) from NCEP. The sea level pressure is contoured, and the vectors are the $10 \mathrm{~m}$ winds. The total heat flux (sensible + latent) is in color, where positive flux corresponds to heat loss from the ocean. The flux corrected product of Moore and Renfrew (2002) has been used. The center of the storm is denoted by the $\mathrm{L}$, and the marginal ice zone along the Labrador shelf is colored white.

Fig 3. Absolute geostrophic pressure anomaly at $700 \mathrm{~m}$ (contours) from Lavender et al. (2000), overlaid on the distribution of surface eddy speed (color) from Lilly et al. (2003). The locations of convection measured by profiling floats in winter 1997 are denoted by the symbols (see legend). The contour interval for the pressure anomaly is $1 \mathrm{~cm}$, and the isobaths are $1000 \mathrm{~m}, 2000 \mathrm{~m}$, and $3000 \mathrm{~m}$. Regions of low geostrophic pressure are indicated by an L.

Fig 4. Potential vorticity at $1000 \mathrm{~m}$ averaged from 1989 to 1997 (excluding wintertime measurements) from Pickart et al. (2003a). This shows the distinct regions of weak stratification in the Labrador and Irminger Seas, respectively. Ocean weather stations Bravo and Alpha are marked, as well as the location of the profiling mooring discussed in section 4. The isobaths are $1000 \mathrm{~m}, 2000 \mathrm{~m}$, and $3000 \mathrm{~m}$, and the CTD station locations are marked by the small grey dots.

Fig 5. Windrose using wintertime data (November to March) from the Prins Christian Sund meteorological station near Cape Farewell. The time period is 1960 to 2000.

Fig 6. Example of the two types of Greenland tip jet: (a) forward tip jet; (b) Reverse tip jet. The surface wind speed (color) and vectors from QuikSCAT are plotted, along with the center of the parent low pressure system (denoted by the L). 
Fig 7. Air parcel trajectories within forward tip jets computed using the Lagranto back trajectory model, from Våge and Davies (2007). (a) Top panel: Velocity of the air parcels (color) showing the acceleration near the tip of Greenland. The contours denote the number of realizations, indicating that most of the trajectories pass to the south of the land mass. (b) Bottom panel: Change in pressure along the trajectories, showing the descent near Greenland.

Fig 8. Climatological average surface wind vectors and wind stress curl (color) over the period 1999 to 2006 from QuikSCAT. The year has been split into two 6-month averages. (a) November to April; (b) May to October.

Fig 9. Results from the study of Pickart et al. (2003b). (a) Final depth of the winter mixed-layer (color) in a regional ocean model forced by repeated occurrences of the forward tip jet. The heat flux of the tip jet is shown by the contours $\left(\mathrm{W} / \mathrm{m}^{2}\right)$. (b) Observed potential vorticity (color) showing newly ventilated water east of Cape Farewell. The heat flux of a forward tip jet event from the COAMPS model is shown by the contours

Fig 10. Comparison of observed and modeled mixed-layers for winter 2002-2003 in the southwestern Irminger Sea, from Vage et al. (2007). Fig 4 shows the location of the mooring. See the key and the discussion in the text for an explanation of the different curves. The vertical lines denote the tip jet events.

Fig 11. Modeled mixed-layer for the winter of 1994-5, from Våge et al. (2007). The different curves are the same as in Fig. 10 (see key).

Fig. 12. Reverse tip jet of Fig $6 \mathrm{~b}$ overlaid on the geostrophic streamfunction of Fig 3 (contours). The wind speed (color) and vectors are shown, as well as the locations of deep convection in winter 1997 from Fig. 3 (black dots). 
Fig 13. Ice chart for 18 March, 2007, from the Danish Meteorological Institute. 


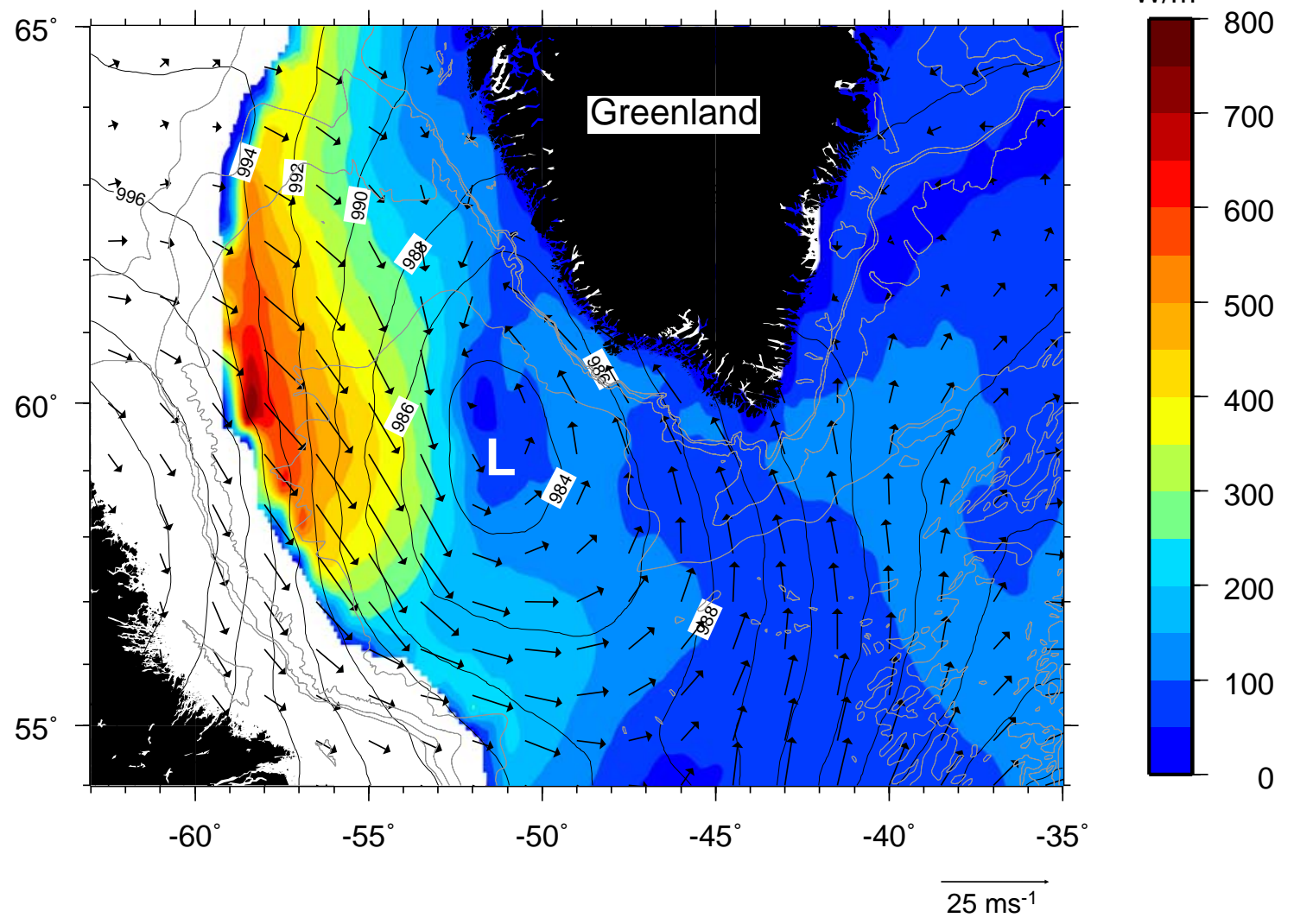




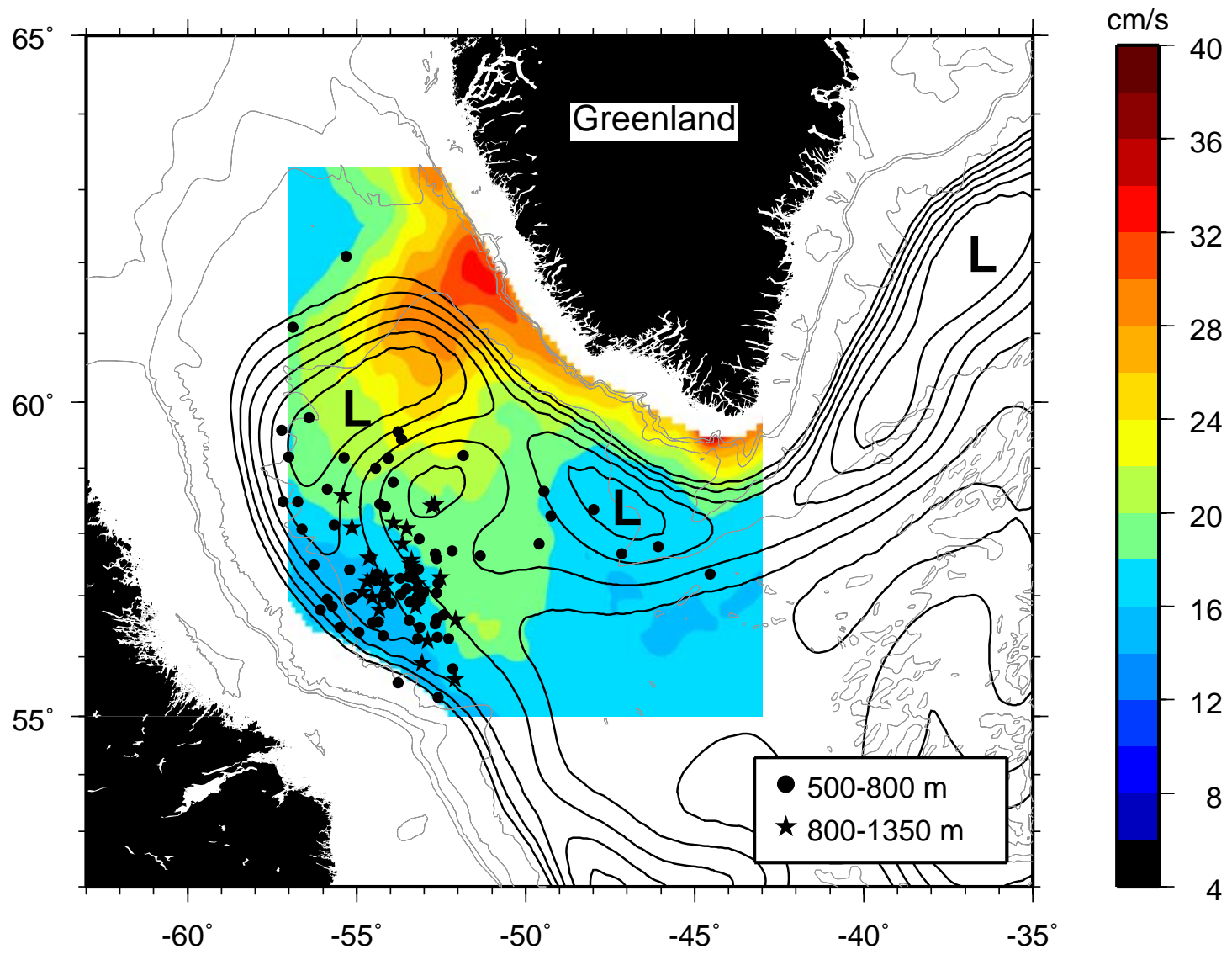


Potential vorticity at $1000 \mathrm{~m}$ (1989-1997)

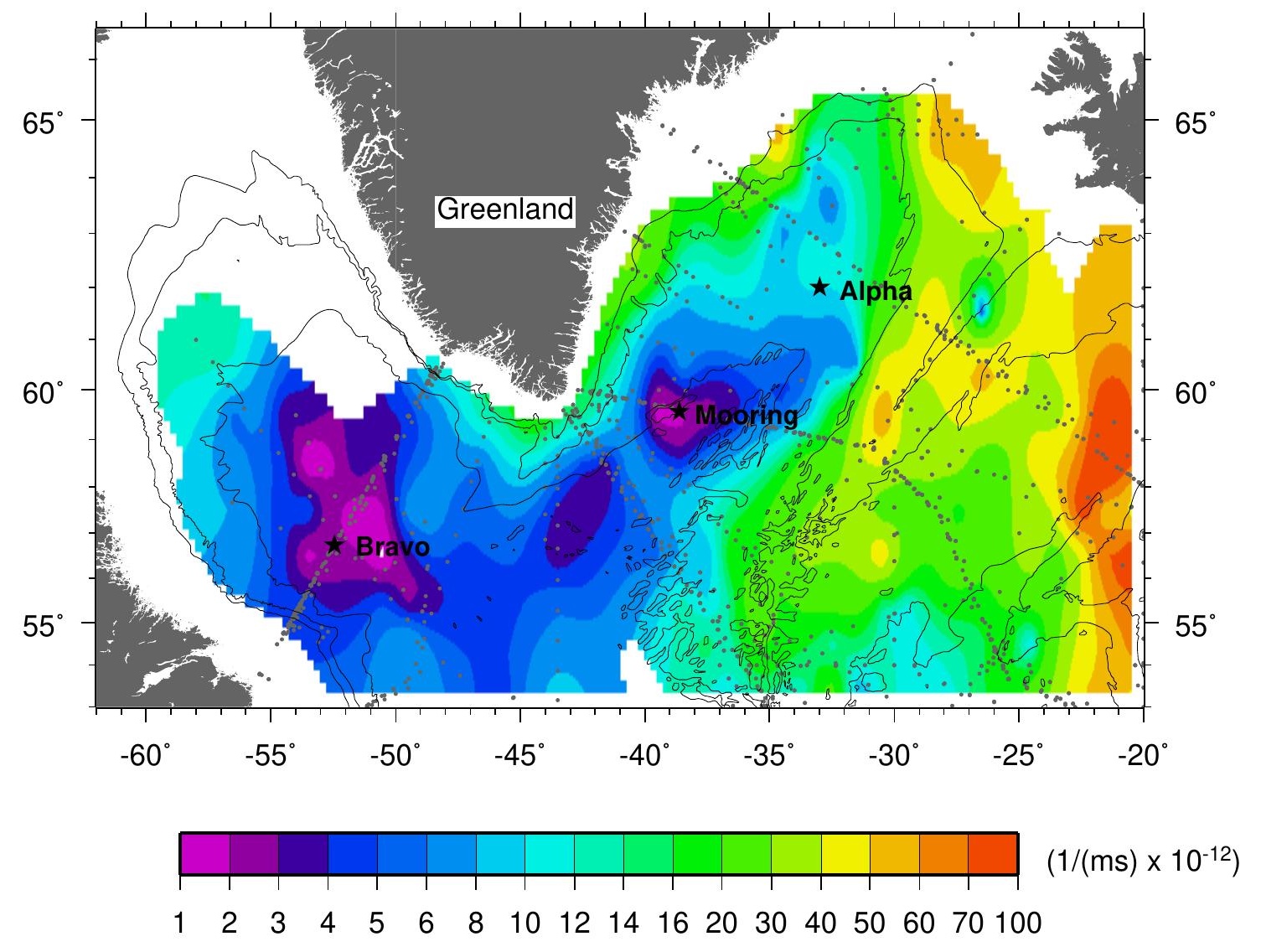


PrinsChrSund $1960 \rightarrow$ 2000: (Nov to Mar)

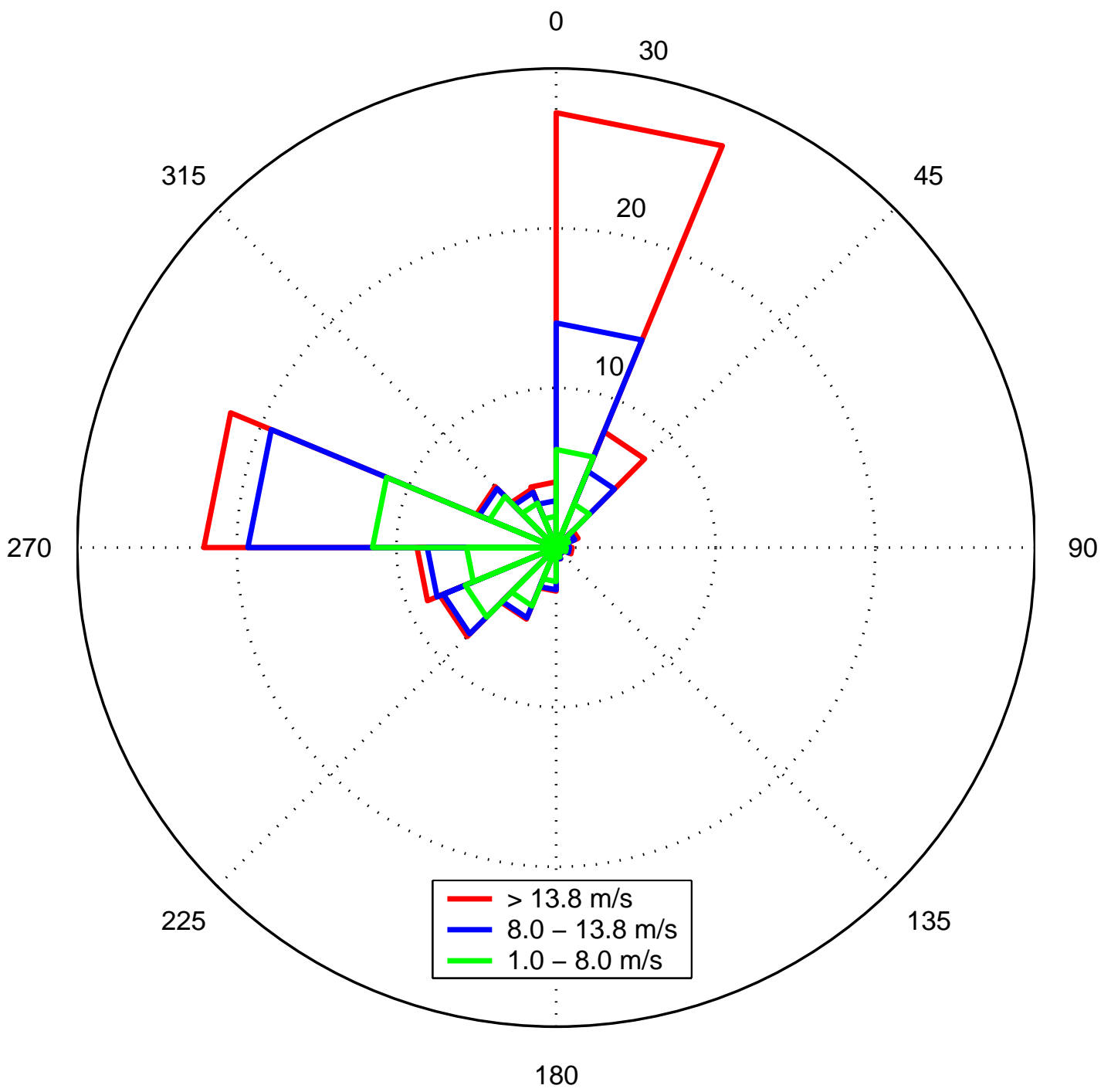


(a) Forward tip jet 5 Dec 2002

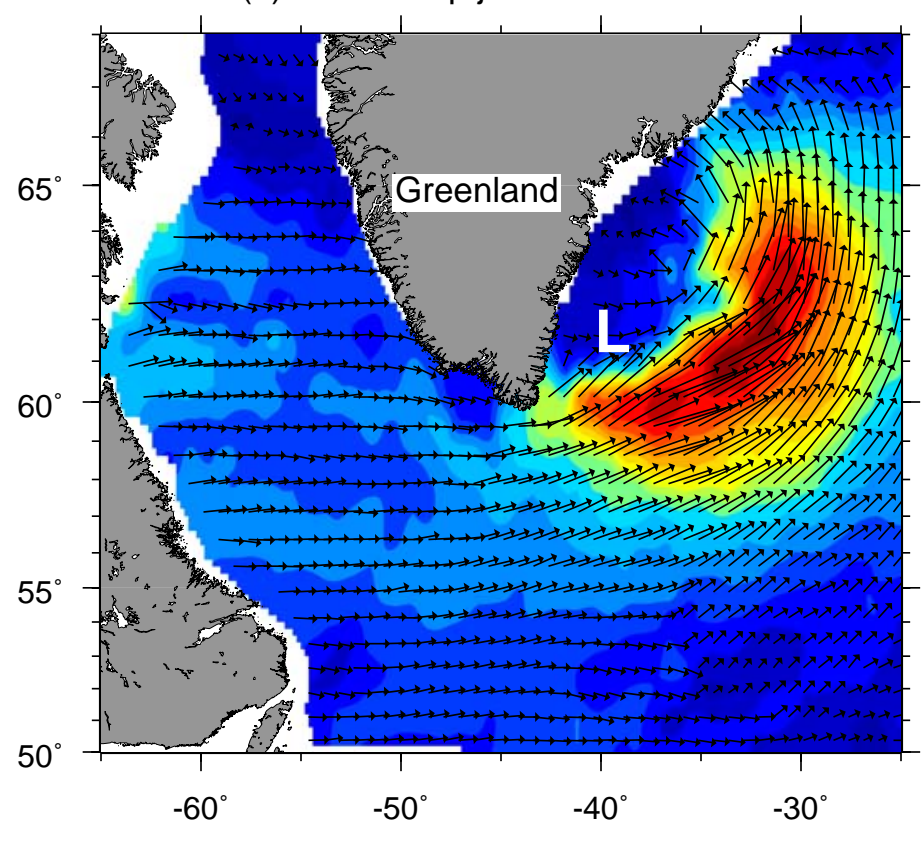

(b) Reverse tip jet 24 Jan 2002

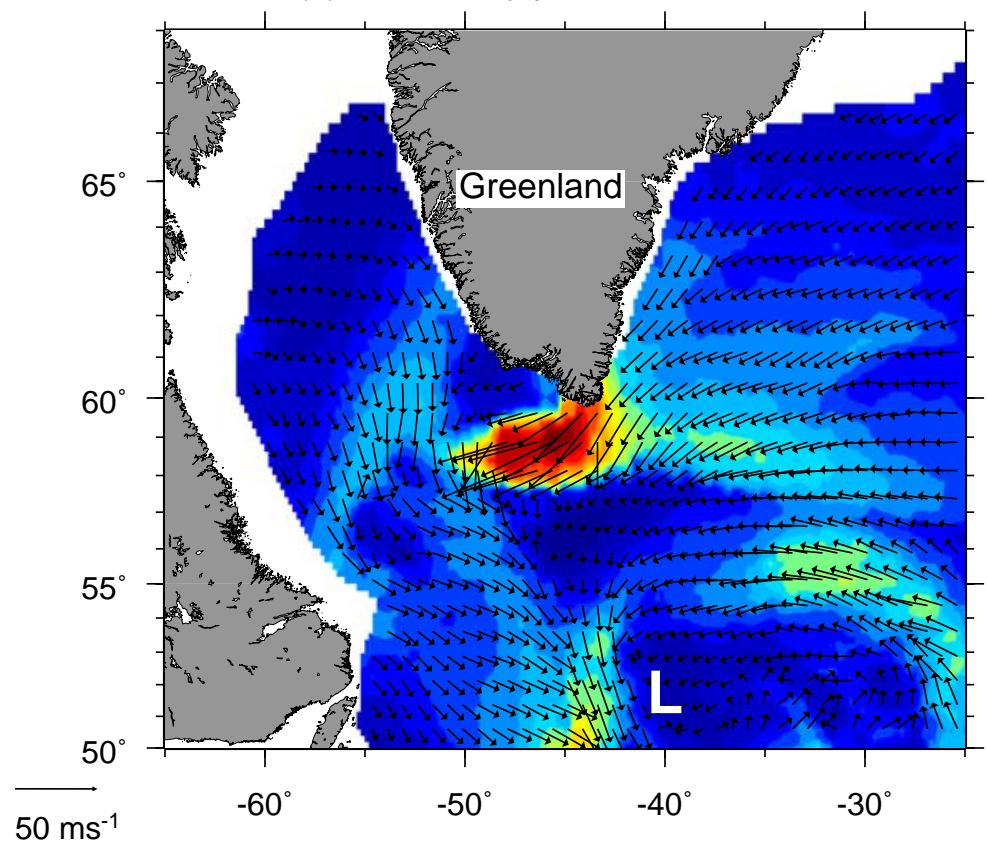

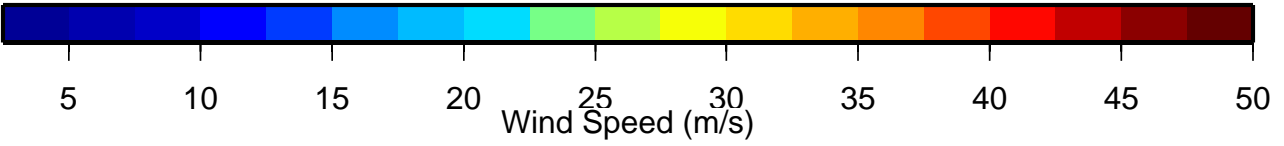




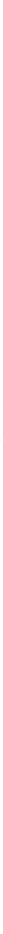




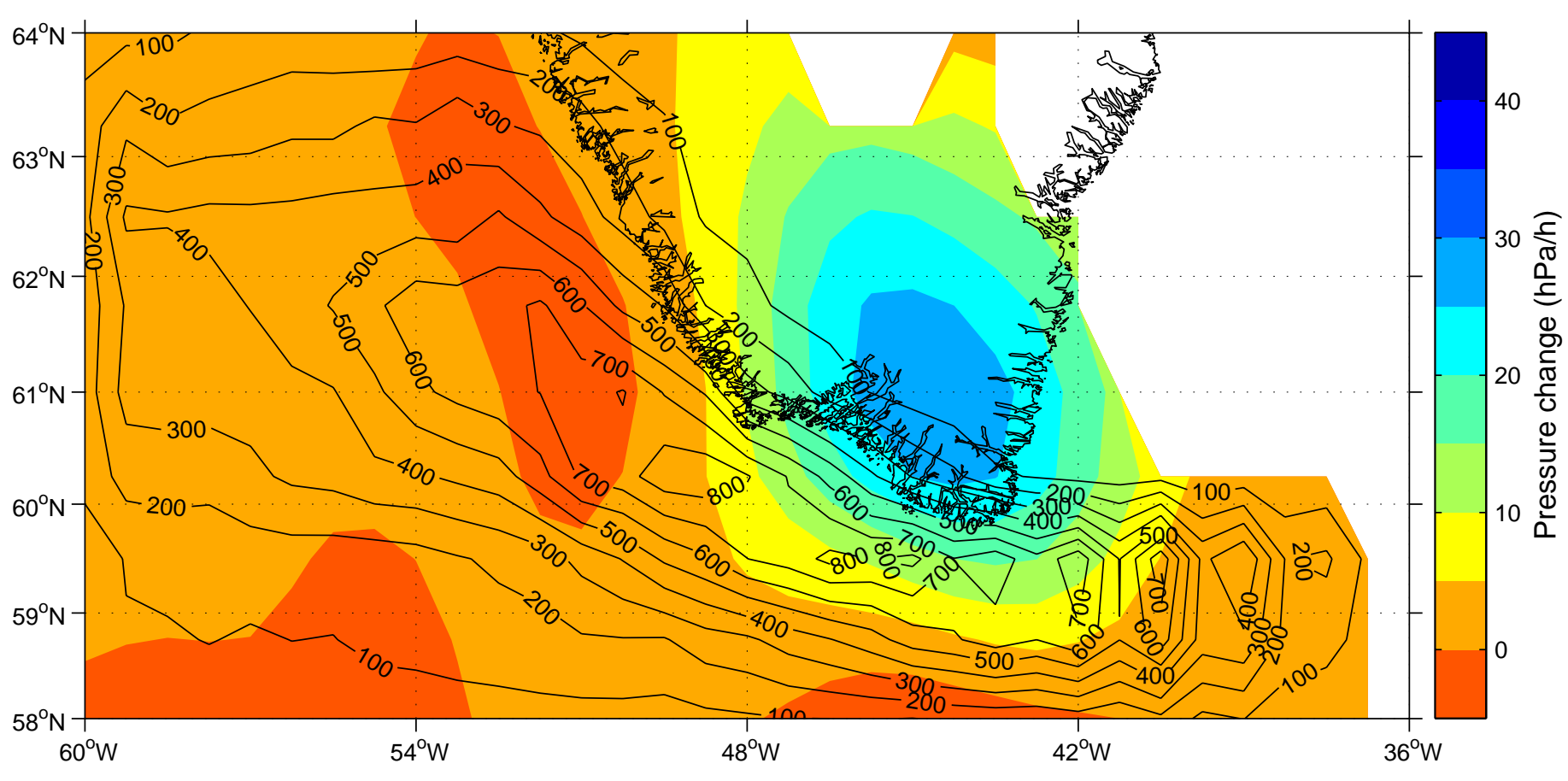



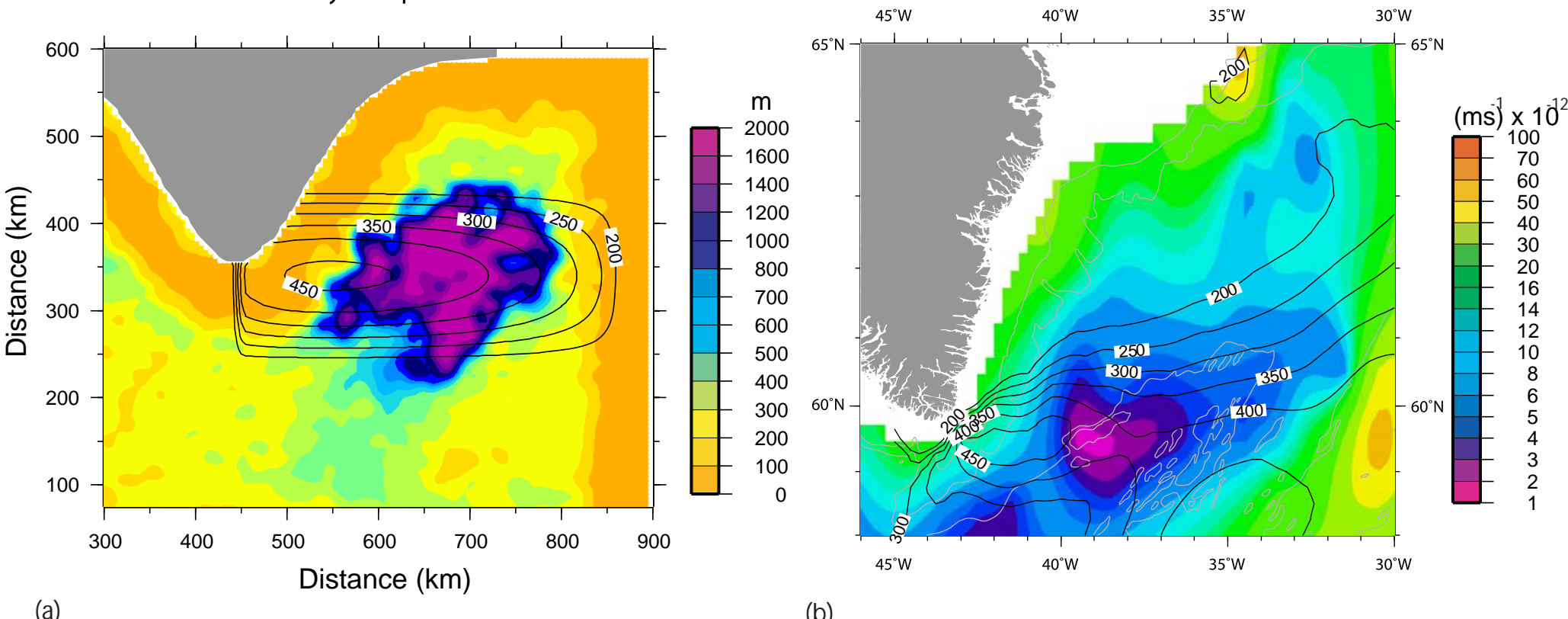

(b) 


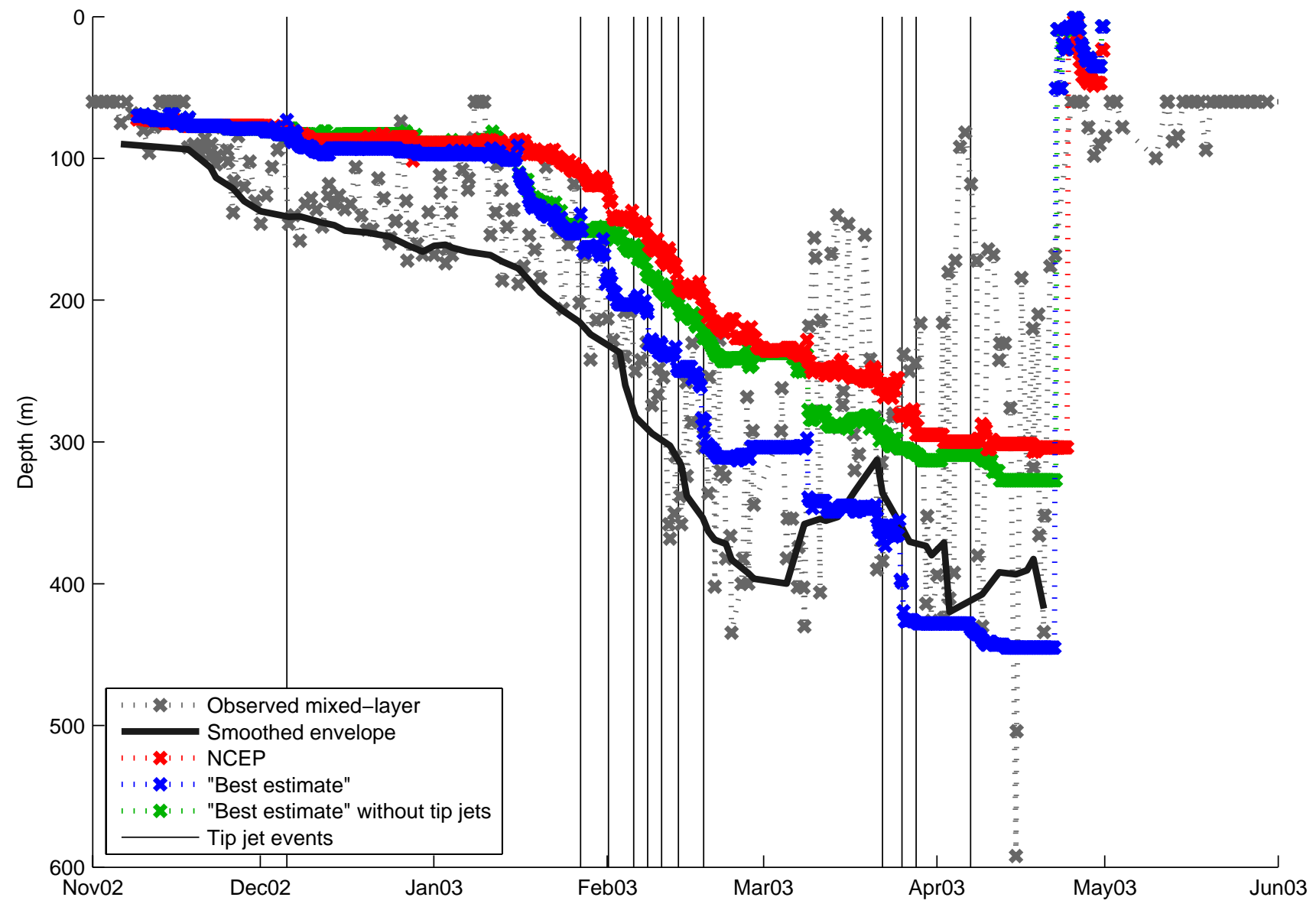




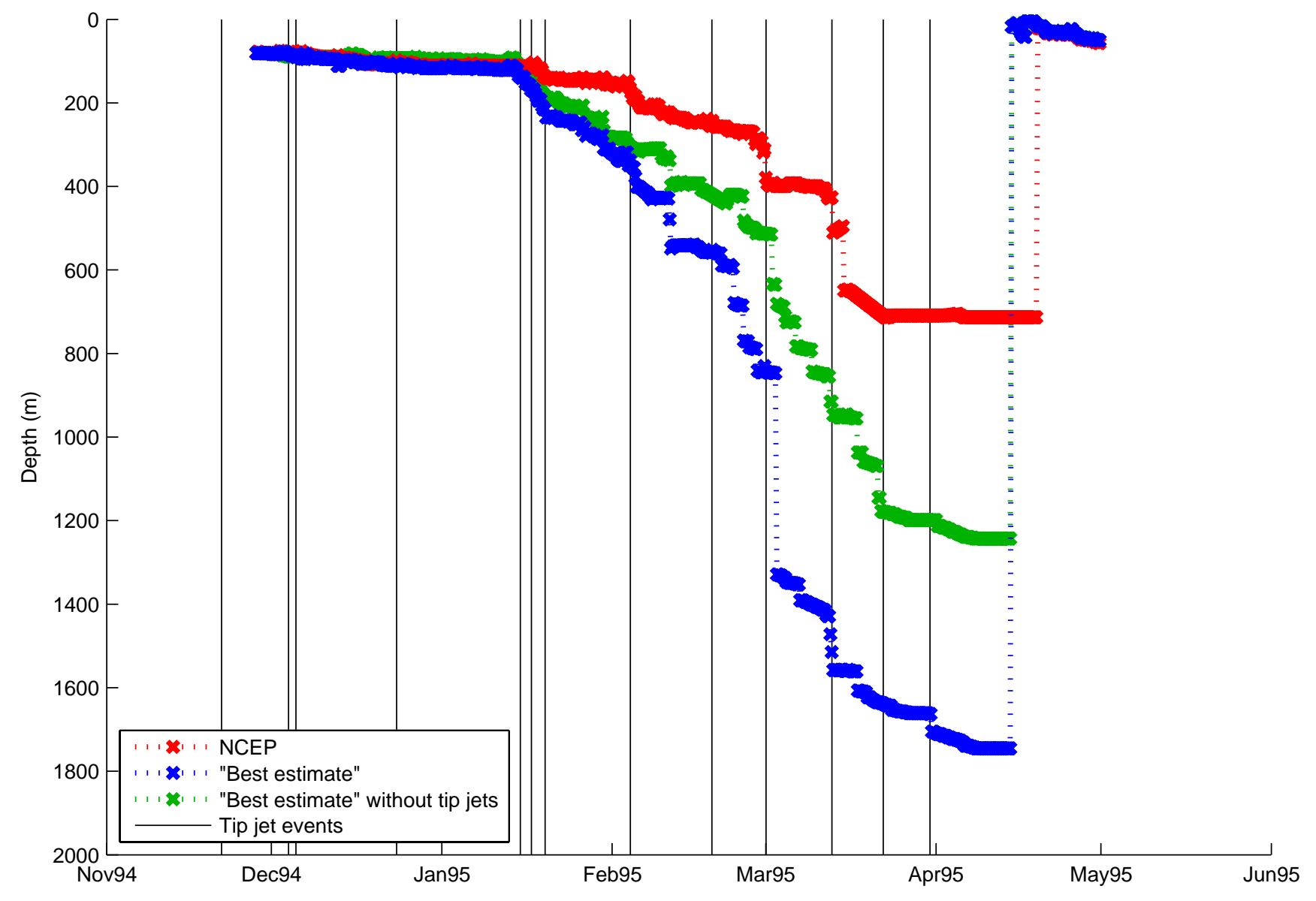




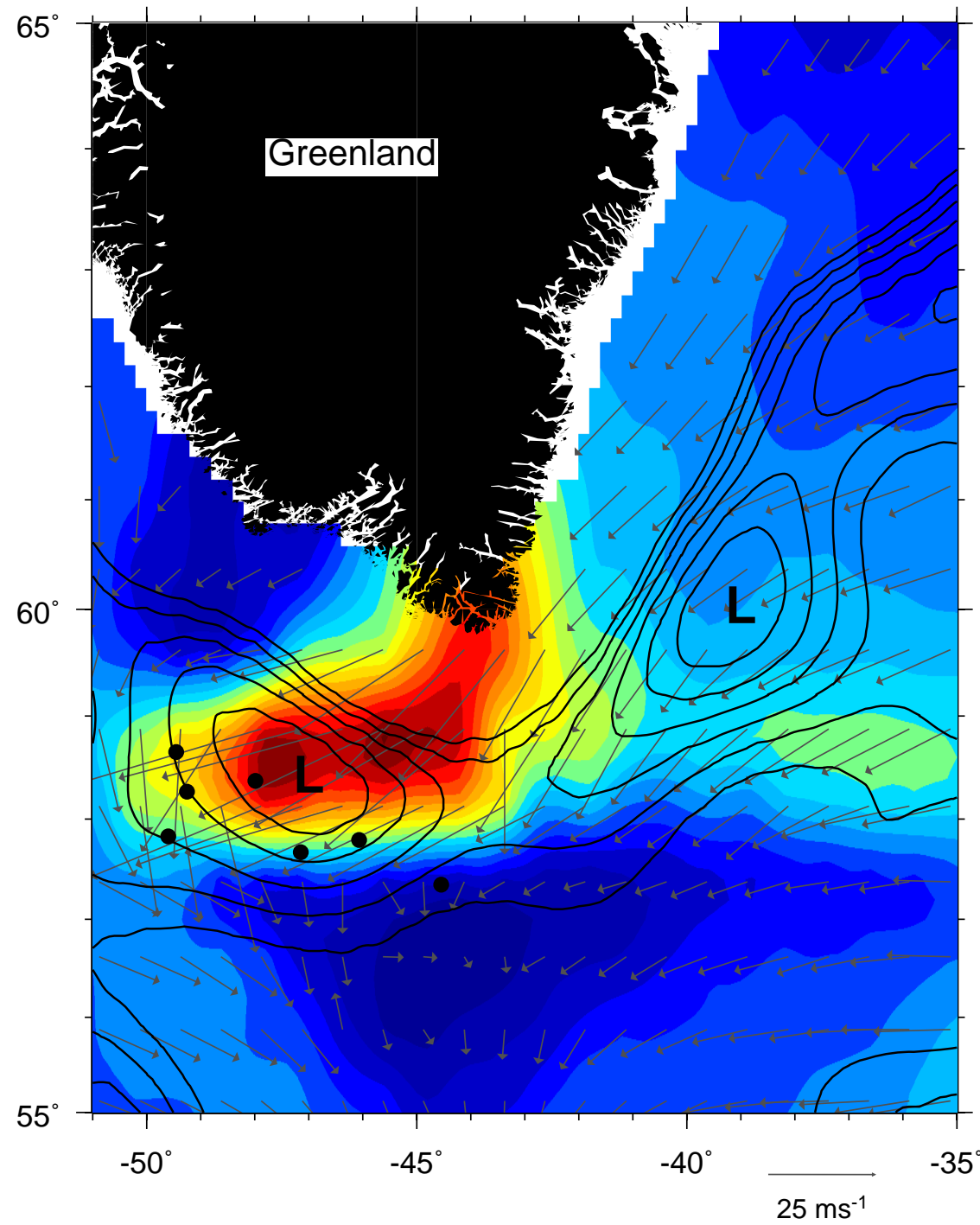

$\mathrm{m} / \mathrm{s}$

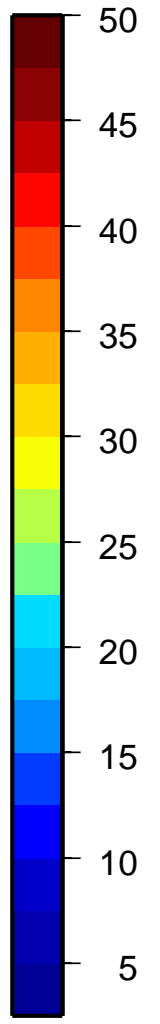




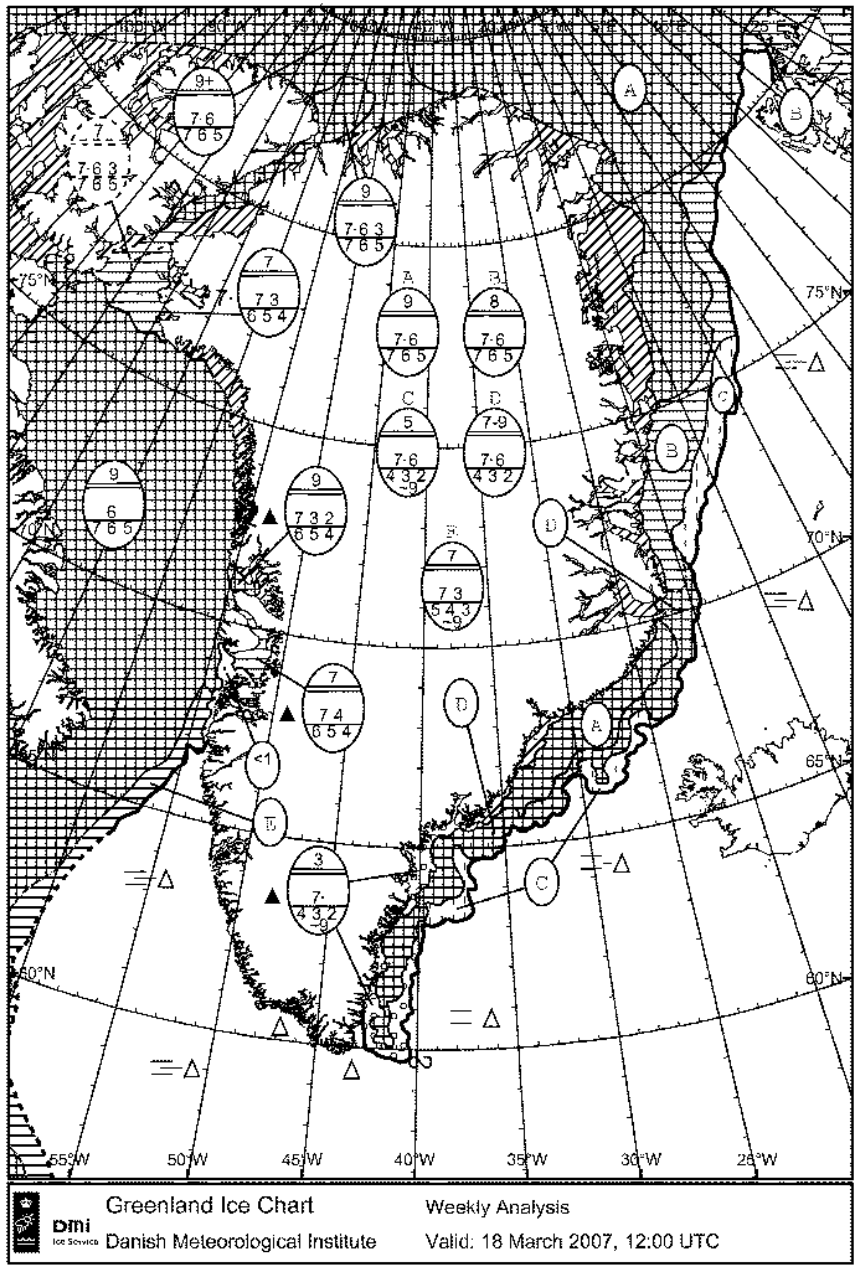

